\title{
SYNTHESIS AND CRYSTAL STRUCTURE OF A NEW Fe(II) a-DIOXIMATE WITH TRIAZINE
}

\author{
O. Ciobanica ${ }^{\mathrm{a}}$, P. Bourosh ${ }^{\mathrm{b}}$, O. Bologa ${ }^{\mathrm{a}}$, I. Bulhac ${ }^{\mathrm{a}}$, V. Lozan ${ }^{\mathrm{a}}$, V. Shofransky ${ }^{\mathrm{a}}$ \\ ${ }^{a}$ Institute of Chemistry, Academy of Sciences of Moldova, 3, Academiei str., \\ MD-2028, Chisinau, R. Moldova; E-mail : ionbulhac@yahoo.com, Phone :+(373 22) 739790 \\ ${ }^{b}$ Institute of Applied Physics, Academy of Sciences of Moldova, 5, Academiei str., MD-2028,Chisinau, \\ R. Moldova;E-mail : bourosh.xray@phys.asm.md,Phone :+(373 22) 738154
}

\begin{abstract}
The interaction of $\left[\mathrm{Fe}(\mathrm{DfgH})_{2} \mathrm{Py}_{2}\right]$ (where $\mathrm{DfgH}=$ monodeprotonated diphenylglyioxime, Py-pyridine) and 1,3,5-triazine (Trz) in chloroform resulted in a new coordination compound with the composition $\left[\mathrm{Fe}(\mathrm{DfgH})_{2}(\mathrm{Trz})_{2}\right] \cdot 2 \mathrm{CHCl}_{3}(\mathbf{1})$. The crystal structure of $\mathbf{1}$, determined by single crystal X-ray diffraction, revealed that $\mathrm{Fe}(\mathrm{II})$ atom is coordinated by four oximic nitrogen atoms of two $\mathrm{DfgH}$ and two nitrogen atoms of two Trz ligands resulting in octahedral surrounding.
\end{abstract}

Keywords: synthesis; Fe(II)dioximate; 1,3,5-triazine, crystal structure

\section{Introduction}

The inner-sphere substitution of apical ligands in $\left[\mathrm{M}(\mathrm{DioxH})_{2} \mathrm{~A}_{2}\right]$ complexes $(\mathrm{M}=$ metal ion, DioxH $=$ monodeprotonated $\alpha$-dioxime and $\mathrm{A}=$ neutral apical ligand) represents an attractive procedure for obtaining new complexes with polyfunctional ligands such as bridgind exo-bidentate or polydentate species. Aromatic [1] and heterocyclic [2, 3] amines, thio- and seleno-carbamides [4, 5] readily enter the inner coordination sphere of dioximates. Generally, such compounds reveal an octahedral surrounding of the metal ion with a stable square-planar $\mathrm{M}(\mathrm{DioxH})_{2}$ building block consolidated by two strong intramolecular hydrogen $\mathrm{O}-\mathrm{H} \cdots \mathrm{O}$ bonds [6]. Various binuclear and polymeric coordination compounds based on $\mathrm{Co}(\mathrm{III}), \mathrm{Cu}(\mathrm{II}), \mathrm{Cd}(\mathrm{II})$ and $\mathrm{Zn}$ (II) dioximates and 4,4'-bipyridyl bridging ligands have been reported [7-10]. It was of particular interest to investigate the complexation process and coordination ability of potentially polydentate heterocyclic amines, in particular, 1,3,5-triazine (Trz). The CSD [11] statistics indicates that the architecture of the molecule Trz, which contains three donor nitrogen atoms, facilitates the formation of polynuclear complexes, three-dimensional networks, various nanoporous materials with $\mathrm{Cu}(\mathrm{II})$ [12-14], $\mathrm{Ru}(\mathrm{II})[15,16], \mathrm{Pt}(\mathrm{II})$ [17] and $\operatorname{Ag}(\mathrm{I})[18,19]$ transition metal ions.

Our contribution describes the reaction of Trz molecule with $\left[\mathrm{Fe}(\mathrm{DfgH})_{2}(\mathrm{Py})_{2}\right]$ which results in the formation of a new compound $\left[\mathrm{Fe}(\mathrm{DfgH})_{2}(\mathrm{Trz})_{2}\right] \cdot 2 \mathrm{CHCl}_{3}(\mathbf{1})$ and X-ray study of these crystals.

\section{Results and discussion}

We recently reported $\mathrm{Co}(\mathrm{III})$ and $\mathrm{Fe}(\mathrm{II})$ dioximates with pyridine and its derivatives, pyrazine and isonicotinamide ligands [3, 20-22]. We have shown the specificity of formation of metal coordination polyhedron, the connection features of these ligands to the central atom and their mutual positions in the complexes. These results demonstrated that various heterocyclic amines coordinate in dioximate-based complexes to the metal ion through one nitrogen atom. The structural studies of (1), which results from the interaction of $\left[\mathrm{Fe}(\mathrm{DfgH})_{2}(\mathrm{Py})_{2}\right]$ with Trz, confirmed the substitution of coordinated Py by Trz molecules. It was determined that the crystal consists of molecular centrosymmetric Fe(II) complexes and crystallization molecules of $\mathrm{CHCl}_{3}$. The metal ion in the complex has a trans-octahedral coordination, similar to those found in transition metal complexes of the general formula $\left[\mathrm{M}(\mathrm{DioxH})_{2} \mathrm{~A}_{2}\right][3,6,20]$.

The coordination polyhedron of the Fe(II) ion is formed by six nitrogen atoms (Figure 1), four of which belong to two bidentate monodeprotonated dioxime $\left(\mathrm{DfgH}^{-}\right)$ligands, and two of monodentate Trz molecules. The CSD analysis [11] showed that in $\mathrm{Cu}(\mathrm{II}), \mathrm{Ru}(\mathrm{II}), \mathrm{Pt}(\mathrm{II})$ and $\mathrm{Ag}(\mathrm{I})$ complexes Trz molecules are quite frequently involved in coordination as tridentate ligands coordinating to the metal atoms through three nitrogen atoms. Thus, trinuclear (e.g. $\mathrm{Pt}(\mathrm{II})$ complex [17]), tetra- and hexanuclear complexes (Cu(II) complexes [12]) or polymeric structures (Cu(II), $\mathrm{Ru}(\mathrm{II})$ and $\operatorname{Ag}(\mathrm{I})$ complexes $[13,15,18,19])$ are formed. However Trz molecules can also act as bidentate bridging ligands $(\mathrm{Cu}$ (II) complexes $[13,14])$, as well as monodentate ligands (complex of $\mathrm{Ru}(\mathrm{II})$ [16]). In the mononuclear molecule of compound (1), two Trz molecules are coordinated to the Fe(II) ion in a monodentate mode. The equatorial plane of the octahedron is defined by two monodeprotonated $\mathrm{DfgH}^{-}$residues, coordinated in a N,N-type chelate mode. The Fe- $\mathrm{N}$ distances in the basal plane have the values of 1.898 (7) and 1.911 (7) $\AA$, and the distance to the apical Trz nitrogen atom is 1.990 (6) $\AA$ (Table 1). In coordination environment of copper, two monodeprotonated oxime residues are linked by the intramolecular $\mathrm{O}-\mathrm{H} \cdots \mathrm{O}$ hydrogen bonds $\left(\mathrm{O}(2)-\mathrm{H} \cdots \mathrm{O}(1)(-x+1,-y,-z) 1.75,2.541(9) \AA, 161^{\circ}\right)$, resulting in the alternation of five-membered chelate rings and six-membered hydrogen-bonded rings (Figure 1). 


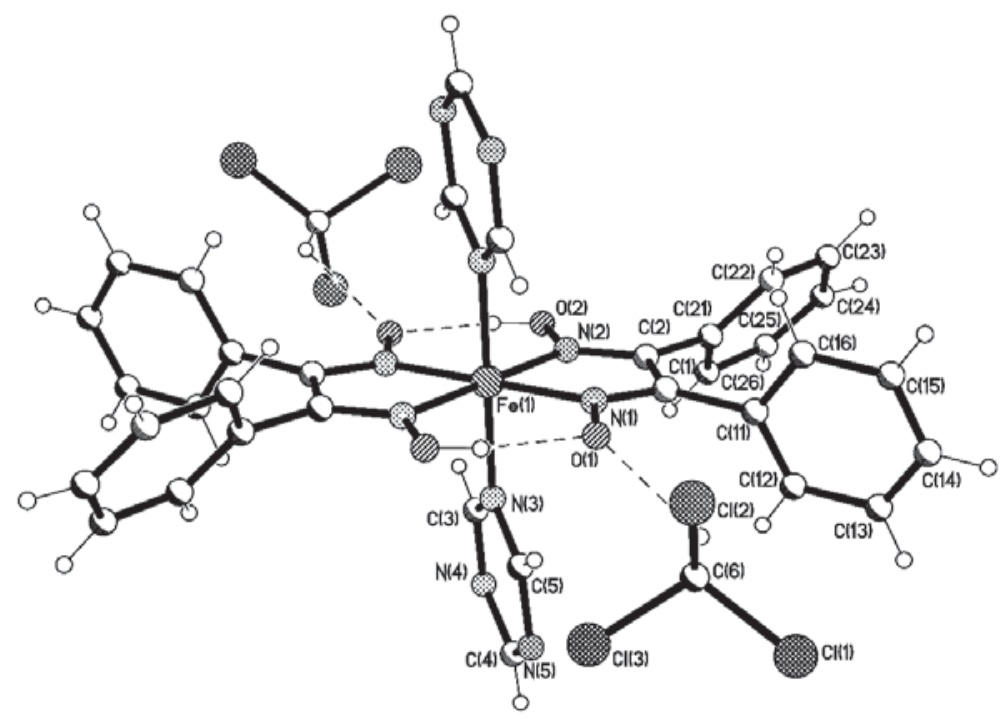

Figure 1. The molecular structure of $\left[\mathrm{Fe}(\mathrm{DfgH})_{2}(\mathrm{Trz})_{2}\right] \cdot 2 \mathrm{CHCl}_{3}$

The dihedral angle between the plane of the Trz ring and the equatorial plane of the coordination polyhedron is equal to $95.3^{\circ}$. Similar arrangement of monodeprotonated $\alpha$-dioximes and neutral ligands which contain nitrogen atoms was also found in iron complexes with imidazole [23, 24], $\beta$-picoline [25], pyrazine [26] and isonicotinamide [3]. The values of interatomic distances and angles for coordinated Trz molecules do not differ significantly from those found in similar complexes of $\mathrm{Cu}(\mathrm{II}), \mathrm{Ru}(\mathrm{II}), \mathrm{Pt}(\mathrm{II})$ and $\mathrm{Ag}(\mathrm{I})$ [13-19].

Table 1

Bond lengths ( $\AA$ ) and angles (deg) for compound (1).

\begin{tabular}{|c|c|c|c|}
\hline Atom-atom & d, $\AA \AA$ & Atom-atom & d, $\AA$ \\
\hline $\mathrm{Fe}(1)-\mathrm{N}(2)$ & $1.898(7)$ & $\mathrm{C}(6)-\mathrm{Cl}(2)$ & $1.740(9)$ \\
\hline $\mathrm{Fe}(1)-\mathrm{N}(1)$ & $1.911(7)$ & $\mathrm{C}(6)-\mathrm{Cl}(1)$ & $1.774(9)$ \\
\hline $\mathrm{Fe}(1)-\mathrm{N}(3)$ & $1.990(6)$ & $\mathrm{C}(6)-\mathrm{Cl}(3)$ & $1.777(9)$ \\
\hline $\mathrm{N}(1)-\mathrm{C}(1)$ & $1.291(10)$ & $\mathrm{C}(11)-\mathrm{C}(16)$ & $1.32(1)$ \\
\hline $\mathrm{N}(1)-\mathrm{O}(1)$ & $1.361(8)$ & $\mathrm{C}(11)-\mathrm{C}(12)$ & $1.33(1)$ \\
\hline$N(2)-C(2)$ & $1.296(11)$ & $\mathrm{C}(12)-\mathrm{C}(13)$ & $1.37(2)$ \\
\hline $\mathrm{N}(2)-\mathrm{O}(2)$ & $1.397(8)$ & $\mathrm{C}(13)-\mathrm{C}(14)$ & $1.32(2)$ \\
\hline $\mathrm{N}(3)-\mathrm{C}(5)$ & $1.343(9)$ & $C(14)-C(15)$ & $1.31(2)$ \\
\hline $\mathrm{N}(3)-\mathrm{C}(3)$ & $1.382(9)$ & $C(15)-C(16)$ & $1.41(2)$ \\
\hline $\mathrm{N}(4)-\mathrm{C}(3)$ & $1.397(10)$ & $\mathrm{C}(21)-\mathrm{C}(22)$ & $1.38(1)$ \\
\hline $\mathrm{N}(4)-\mathrm{C}(4)$ & $1.426(11)$ & $\mathrm{C}(21)-\mathrm{C}(26)$ & $1.39(1)$ \\
\hline$N(5)-C(4)$ & $1.390(11)$ & $\mathrm{C}(22)-\mathrm{C}(23)$ & $1.38(2)$ \\
\hline $\mathrm{N}(5)-\mathrm{C}(5)$ & $1.409(10)$ & $\mathrm{C}(23)-\mathrm{C}(24)$ & $1.38(3)$ \\
\hline$C(1)-C(11)$ & $1.47(1)$ & $\mathrm{C}(24)-\mathrm{C}(25)$ & $1.31(3)$ \\
\hline$C(1)-C(2)$ & $1.492(11)$ & $C(25)-C(26)$ & $1.45(2)$ \\
\hline $\mathrm{C}(2)-\mathrm{C}(21)$ & $1.50(1)$ & & \\
\hline Atom-atom-atom & $\omega, \operatorname{grad}$ & Atom-atom-atom & $\omega$, grad \\
\hline $\mathrm{N}(1)-\mathrm{Fe}(1)-\mathrm{N}(2)$ & $79.8(3)$ & $\mathrm{N}(3)-\mathrm{C}(3)-\mathrm{N}(4)$ & $122.8(8)$ \\
\hline $\mathrm{N}(1)-\mathrm{Fe}(1)-\mathrm{N}(2) \# 1$ & $100.2(3)$ & $\mathrm{N}(5)-\mathrm{C}(4)-\mathrm{N}(4)$ & $119.1(7)$ \\
\hline $\mathrm{N}(1)-\mathrm{Fe}(1)-\mathrm{N}(3)$ & $90.0(3)$ & $\mathrm{N}(3)-\mathrm{C}(5)-\mathrm{N}(5)$ & $124.0(7)$ \\
\hline $\mathrm{N}(1)-\mathrm{Fe}(1)-\mathrm{N}(3) \# 1$ & $90.0(3)$ & $\mathrm{Cl}(2)-\mathrm{C}(6)-\mathrm{Cl}(1)$ & $110.4(5)$ \\
\hline $\mathrm{N}(2)-\mathrm{Fe}(1)-\mathrm{N}(3)$ & $88.9(3)$ & $\mathrm{Cl}(2)-\mathrm{C}(6)-\mathrm{Cl}(3)$ & $111.4(5)$ \\
\hline $\mathrm{N}(2)-\mathrm{Fe}(1)-\mathrm{N}(3) \# 1$ & $91.1(3)$ & $\mathrm{Cl}(1)-\mathrm{C}(6)-\mathrm{Cl}(3)$ & $109.1(4)$ \\
\hline $\mathrm{C}(1)-\mathrm{N}(1)-\mathrm{O}(1)$ & $119.7(7)$ & $C(16)-C(11)-C(12)$ & $117.3(11)$ \\
\hline $\mathrm{C}(1)-\mathrm{N}(1)-\mathrm{Fe}(1)$ & $118.9(6)$ & $\mathrm{C}(16)-\mathrm{C}(11)-\mathrm{C}(1)$ & $119.8(10)$ \\
\hline
\end{tabular}




\begin{tabular}{l|c|c|c}
$\mathrm{O}(1)-\mathrm{N}(1)-\mathrm{Fe}(1)$ & $121.1(6)$ & $\mathrm{C}(12)-\mathrm{C}(11)-\mathrm{C}(1)$ & $122.9(8)$ \\
$\mathrm{C}(2)-\mathrm{N}(2)-\mathrm{O}(2)$ & $119.3(7)$ & $\mathrm{C}(11)-\mathrm{C}(12)-\mathrm{C}(13)$ & $121.8(11)$ \\
$\mathrm{C}(2)-\mathrm{N}(2)-\mathrm{Fe}(1)$ & $118.0(6)$ & $\mathrm{C}(14)-\mathrm{C}(13)-\mathrm{C}(12)$ & $120.5(12)$ \\
$\mathrm{O}(2)-\mathrm{N}(2)-\mathrm{Fe}(1)$ & $122.7(6)$ & $\mathrm{C}(15)-\mathrm{C}(14)-\mathrm{C}(13)$ & $119.2(12)$ \\
$\mathrm{C}(5)-\mathrm{N}(3)-\mathrm{C}(3)$ & $117.3(7)$ & $\mathrm{C}(14)-\mathrm{C}(15)-\mathrm{C}(16)$ & $119.8(11)$ \\
$\mathrm{C}(5)-\mathrm{N}(3)-\mathrm{Fe}(1)$ & $122.3(5)$ & $\mathrm{C}(11)-\mathrm{C}(16)-\mathrm{C}(15)$ & $121.2(12)$ \\
$\mathrm{C}(3)-\mathrm{N}(3)-\mathrm{Fe}(1)$ & $120.2(5)$ & $\mathrm{C}(22)-\mathrm{C}(21)-\mathrm{C}(26)$ & $120.9(11)$ \\
$\mathrm{C}(3)-\mathrm{N}(4)-\mathrm{C}(4)$ & $118.3(8)$ & $\mathrm{C}(26)-\mathrm{C}(21)-\mathrm{C}(2)$ & $118.8(9)$ \\
$\mathrm{C}(4)-\mathrm{N}(5)-\mathrm{C}(5)$ & $118.4(8)$ & $\mathrm{C}(21)-\mathrm{C}(22)-\mathrm{C}(23)$ & $120.4(11)$ \\
$\mathrm{N}(1)-\mathrm{C}(1)-\mathrm{C}(11)$ & $125.1(8)$ & $\mathrm{C}(24)-\mathrm{C}(23)-\mathrm{C}(22)$ & $121.5(13)$ \\
$\mathrm{N}(1)-\mathrm{C}(1)-\mathrm{C}(2)$ & $110.6(8)$ & $\mathrm{C}(25)-\mathrm{C}(24)-\mathrm{C}(23)$ & $118(2)$ \\
$\mathrm{C}(11)-\mathrm{C}(1)-\mathrm{C}(2)$ & $124.2(9)$ & $\mathrm{C}(24)-\mathrm{C}(25)-\mathrm{C}(26)$ & $122(2)$ \\
$\mathrm{N}(2)-\mathrm{C}(2)-\mathrm{C}(1)$ & $112.6(8)$ & $\mathrm{C}(21)-\mathrm{C}(26)-\mathrm{C}(25)$ & $122(2)$ \\
$\mathrm{N}(2)-\mathrm{C}(2)-\mathrm{C}(21)$ & $123.5(8)$ & & $116(1)$ \\
$\mathrm{C}(1)-\mathrm{C}(2)-\mathrm{C}(21)$ & $123.9(9)$ & &
\end{tabular}

Symmetry transformations used to generate equivalent atoms: $\# 1-x+1,-y,-z$.

The crystal packing of compound $\mathbf{1}$ is shown in Figure 2. The structure is molecular; the complexes are located close to the center of the symmetry of the orthorhombic Pbca space group, forming channels with a $27 \%$ of the total crystal volume. In these channels, the solvate $\mathrm{CHCl}_{3}$ molecules are encapsulated and linked to the complexes by weak hydrogen-bond interactions $\left(\mathrm{C}(6)-\mathrm{H} \cdots \mathrm{O}(1)(x, y, z) 0.98,2.27,2.966 \AA, 127^{\circ}\right)$ (Figure 2).

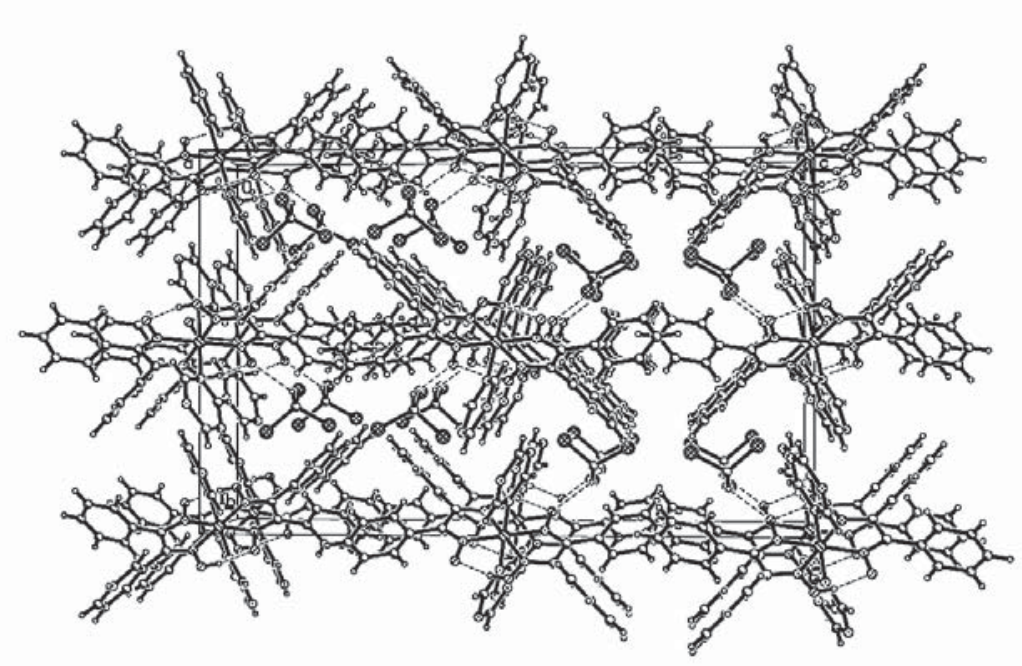

Figure 2. Fragment of crystal packing in 1.

The IR spectrum of 1 confirms the presence of all organic ligands used in the synthesis process [27, 28]. The characteristic bands of the Trz ligands were assigned as following: the weak intensity band at $3054 \mathrm{~cm}^{-1}$ was attributed to $v(=\mathrm{C}-\mathrm{H})$ vibration; a series of six weak intensity bands within $2000-1660 \mathrm{~cm}^{-1}-$ to overtones and vibrations typical to mono- and 1,3,5-substituted aromatic; $1069 \mathrm{~cm}^{-1}-$ to $\left(\delta_{\text {plane }}(\mathrm{CH})\right.$ of mono- and 1,3,5-substituted aromatic. The presence of $\mathrm{DfgH}^{-}$is documented by the characteristic oscillations $v_{\text {as }}\left(\mathrm{CH}_{2}\right)=2931, \delta(\mathrm{OH})=1730, \delta_{\text {as }}\left(\mathrm{CH}_{2}\right)=1450$ and $\delta(\mathrm{C}=\mathrm{N}-\mathrm{O})=731 \mathrm{~cm}^{-1}$.

\section{Experimental}

All reagents and solvents were obtained from commercial sources and were used without further purification. Elemental analysis was performed on an Elementar Analysensysteme GmbH Vario El III elemental analyzer. The IR spectra were obtained in Vaseline on a FT IR Spectrum-100 Perkin Elmer spectrometer in 400-4000 $\mathrm{cm}^{-1} \mathrm{range}_{\text {. }}$ 
Synthesis. To [Fe(DfgH) $\left.)_{2} \mathrm{Py}_{2}\right](0.17 \mathrm{~g}, 0.245 \mathrm{mmol})$ dissolved in $20 \mathrm{~mL}$ of chloroform Trz $(0.05 \mathrm{~g}, 0.615 \mathrm{mmol})$ dissolved in $10 \mathrm{~mL}$ of methyl alcohol was added. The resulted crystals of hexagonal habitus were collected from the dark-cherry solution. Yield: $\sim 60 \%$. The crystals are insoluble in water and alcohol. Anal. found for $\mathrm{C}_{36} \mathrm{H}_{30} \mathrm{Cl}_{6} \mathrm{Fe}_{1} \mathrm{~N}_{10} \mathrm{O}_{4}$, \%: Fe 6,05; C 46,28; H 3,18; N 14,75. Calculated: Fe 5,97; C 46,23; H 3,23; N 14,98.

$X$-ray Crystallography. Diffraction measurement for 1 was carried out at room temperature on a STOE IPDS diffractometer equipped with a graphite monochromator utilizing $\operatorname{MoK} \alpha(\lambda=0.71073 \AA)$ radiation and $\omega$ scans. Final unit cell dimensions were obtained and refined on an entire data set. The crystal structure was solved by direct methods. All calculations to solve the structures and to refine the models were carried out with the programs SHELXS97 and SHELXL97 [29]. The $\mathrm{C}$-bound $\mathrm{H}$ atoms were placed in calculated positions and were treated using a riding model approximation with $\mathrm{U}_{\text {iso }}(\mathrm{H})=1.2 \mathrm{U}_{\text {eq }}(\mathrm{C})$, while the $\mathrm{O}$-bound $\mathrm{H}$-atoms were found from differential Fourier maps at intermediate stages of the refinement and their positions were constrained using the AFIX 83 instruction in SHELXL for oxime groups. These hydrogen atoms were refined with isotropic displacement parameter $U_{\text {iso }}(H)=1.5 U_{\text {eq }}(O)$. Crystal data and details on the structure refinement are given in Table 2. Selected geometric parameters for $\mathbf{1}$ are given in Table 1. CCDC 933171 contains the supplementary crystallographic data for $\mathbf{1}$.

Table 2

Crystal data and structure refinement for compound (1).

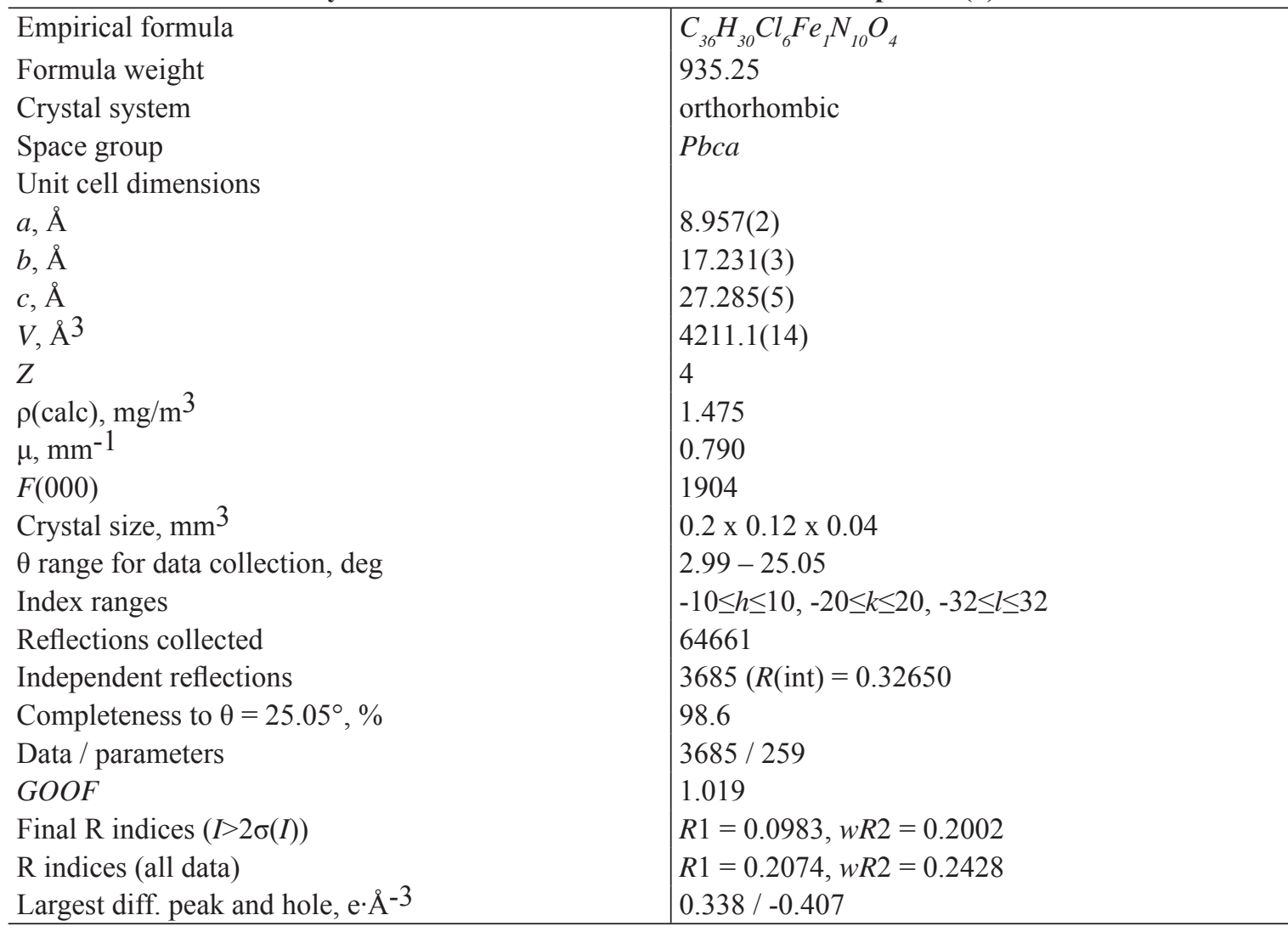

\section{References}

[1]. Melnic, E. Bourosh P.; Rija, A.; Lipkowski, J.; Bologa, O.A.; Bulhac, I.; Coropceanu, E.; and Shafranski, V.N. Rus. J. Coord. Chem. 2012, 38(9), 623-633.

[2]. Coropceanu, E.B.; Rija, A.P.; Lozan, V.I.; Bologa, O.A.; Boldisor, A.A.; Bulhac, I.I.; Kravtsov, V. Ch.; Bourosh, P.N. Russ. J. Coord. Chem. 2012, 38(8), 545-551.

[3]. Bulhac, I.I.; Bourosh, P.N.; Schollmeyer, D.; Zubareva, V.E.; Suwinska, K.; Ciobanica, O.; and Simonov, Yu.A. Russ. J. Coord. Chem. 2009, 35(5), 352-359.

[4]. Bourosh, P.N.; Coropceanu, E.B.; Rija, A.P.; Bologa, O.A.; Gdaniec, M.; Bulhac, I.I. J. Mol. Struct. 2011, 998, 198-205.

[5]. Rija, A.P.; Nicolescu, A.; Soran, A.; Coropceanu, E.B.; Bulhac, I.I.; Bologa, O.A.; Deleanu, C.; and Bourosh, P.N. Rus. J. Coord. Chem. 2011, 37(10), 757-765.

[6]. Botoshanskii, M.M.; Dvorkin, A.A.; Simonov, Yu.A.; Malinowskii, T.I. Stroenie dimethylglioximatov 
perehodnykh metallov. In Kristallicheskie struktury neorganicheskikh soedinenii. Izd-vo. Shtiintsa: Kishinev, $1974 ; 26-61$.

[7]. Bourosh, P.; Coropceanu, E.; Kravtsov, V.; Bologa, O.A.; Shafranski, V.N.; Bulhac, I. The XVII-th International Conference „Physical Method in Coordination and Supramolecular Chemistry”, Book of Abstracts, P13, Chisinau, October, 24-26, 2012, p. 61.

[8]. Coropceanu, Ed. B.; Croitor, L.; Botoshansky, M. M.; Siminel, A. V.; Fonari, M. S. Polyhedron. 2011, 30, 2592-2598.

[9]. Croitor, L.; Coropceanu, Ed. B.; Siminel, A.V.; Kravtsov, V. Ch.; Fonari, M.S. Cryst. Growth\& Design, 2011, 11, 3536-3544.

[10]. Croitor, L.; Coropceanu, Ed.B.; Siminel, A.V.; Kulikova, O.; Zelentsov, V.I.; Datsko, T.; Fonari, M.S. CrystEngComm. 2012, 14, 3750-3758.

[11]. Allen, F.H. Acta Crystallogr. 2002, 58B(3-4), 380-388.

[12]. Pike, R.D.; Borne, B.D.; Maeyer, J.T.; Rheingold, A.L. Inorg. Chem. 2002, 41, p. 631-633.

[13]. Blake, A.J.; Brooks, N.R.; Champness, N.R.; Cooke, P.A.; Deveson, A.M.; Fenske, D.; Hubberstey, P.; Li, W.-Sh.; Schroder, M. J. Chem. Soc., Dalton Trans. 1999, 2103-2110.

[14]. Maeyer, J.T.; Johnson, T.J.; Smith, A.K.; Borne, B.D.; Pike, R.D.; Pennington, W.T.; Krawiec, M.; Rheingold, A.L. Polyhedron. 2003, 22, 419-431.

[15]. Furukawa, S.; Ohba, M.; Kitagawa, S. Chem. Commun. 2005, p. 865-867.

[16]. Garcia, M.H.; Morais, T.S.; Florindo, P.; Piedade, M.F.M.; Moreno, V.; Ciudad, C.; Noe, V. J. Inorg. Biochem. 2009, 103, $354-361$.

[17]. Kaufman, W.; Venanzi, L.M.; Albinati, A. Inorg.Chem. 1988, 27, 1178-1187.

[18]. Venkataraman, D.; Lee, S.; Moore, J.S.; Zhang, P.; Hirsch, K.A.; Gardner, G.B.; Covey, A.C.; Prentice, C.L. Chem. Mater. 1996, 8, 2030-2040.

[19]. Bertelli, M.; Carlucci, L.; Ciani, G.; Proserpio, D.M.; Sironi, A. J. Mater. Chem. 1997, 7, 1271-1276.

[20]. Bulhac, I.; Bouros, P.N.; Bologa, O.A.; Lozan, V.; Ciobanica, O.; Lipkowski, J.; Mitina, T.F.; Simonov, Yu.A. Rus. J. Inorg. Chem. 2010, 55(7), 1042-1051.

[21]. Chiobenika, O.; Bourosh, P.; Lozan, V.; Bologa, O.; Bulhak, I.; Wicher, B.; Simonov, Yu. Rus. J. Inorg. Chem. 2011, 56(7), 1054-1063.

[22]. Bourosh, P.; Ciobanica, O.; Lozan, V.; Bulhac, I. Rus. J. Coord. Chem. 2012, 38(7), 461-470.

[23]. Bowman, K.; Gaughan, A.P.; Dori, Z. J. Am. Chem. Soc. 1972, 94(3), 727-731.

[24]. Prout, C.K.; Wiseman, T.J. J. Chem. Soc. 1964, No1, 497-504.

[25]. Dvorkin, A.A.; Simonov, Yu.A.; Malinovskii, T.I.; Bulgak, I.I.; Batir, D.G. Dokl. Akad. Nauk SSSR(Russ.)(Proc. Nat. Acad. Sci. USSR), 1977, 234(6), 1372-1375.

[26]. Kubel, F.; Strahle, J. Z. Naturforsch. B: Chem. Sci. 1983, 38(2), 258-259.

[27]. Bellami, L. Infrakrasnye spektry slozhnykh molecul. Izd-vo inostr. lit. Moskva. 1963. 590 p.

[28]. Khakanisi, K. Infrakrasnye spektry i stroenie organicheskikh soedinenii. Izd-vo "Mir". 1965. 216 p.

[29]. Sheldrick, G.M. Acta Cryst. 2008, A64, 112-122. 